\title{
The Effect of in vitro Enzyme Digestion on Antioxidant and Anticholinesterase Potential of Tomato (Lycopersicum esculentum) Fruit and Two Commercially Processed Tomato Pastes
}

\author{
Sule O. Salawu ${ }^{2}$, b , Olatunde F. Faloye ${ }^{\mathrm{a}}$, Bukola B. Ola-Salawu ${ }^{\mathrm{b}}$, and \\ Akintunde A. Akindahunsi ${ }^{\mathrm{a}}$ \\ ${ }^{\text {a }}$ Department of Biochemistry, Federal University of Technology, Akure, Ondo State, Nigeria \\ ${ }^{\mathrm{b}}$ Department of Biochemistry, Osun State University, Osogbo, Osun State, Nigeria \\ ${ }^{\mathrm{c}}$ Department of Biology, Federal University of Technology, Akure, Ondo State, Nigeria \\ ${ }^{*}$ Corresponding author \\ sosalawu@futa.edu.ng \\ TEL: +2348132595807
}

Received: 10 September 2018; Published online: 18 January 2020

\begin{abstract}
Tomato is a horticultural crop of interest, that is widely consumed fresh or as processed products. The present investigation was to evaluate the antioxidant indices (total phenolic content, flavonoid content, ferric reducing antioxidant power, radical scavenging activities, inhibitory action against lipid oxidation) and anti-cholinesterase action (acetylcholinesterase and butyrylcholinesterase) of tomato fruits (ripe and unripe) and pastes (paste 2 and paste 1) after simulated gastrointestinal digestion. The total phenolic content (mg/g GAE) of the in vitro digested tomato fruits and pastes showed higher values (ripe tomato: 61.08; tomato paste1: 56.02; tomato paste 2: 60.36; unripe tomato: 38.97) than the ethanolic extracts, with digested ripe tomato ranking higher. Similar results were also obtained for total flavonoid content, ferric reducing antioxidant power, and the radical scavenging activities $\left(\mathrm{DPPH}^{*}, \mathrm{ABTS}^{+}, \mathrm{NO}^{*}, \mathrm{OH}^{*}\right)$, with the in vitro digested samples ranking high. The ability of the enzyme digested and ethanolic extracts of tomato fruits and pastes to inhibit iron and sodium nitroprusside induced lipid oxidation in rat's liver and brain homogenate increased in a concentration dependent manner, with the enzyme digested tomato fruits and pastes ranking high. Similarly, the ability of the in vitro digested tomato fruit and pastes to enhance activities of the antioxidant enzymes (GPx, GSH, SOD and Catalase) and to inhibit the formation of cholinesterases ranked high. The result of this investigation showed that the studied tomato fruit and pastes possess antioxidant and anti-cholinesterase activities that would be bio-available after the gastrointestinal digestion and by implication could be harnessed as functional food.
\end{abstract}

Keywords: in vitro Digestion; Antioxidant activities; Anticholinesterase Potential; Tomato fruit; Commercially- processed Tomato pastes

\section{Introduction}

Antioxidants are compounds that help to inhibit many oxidation reactions caused by free radicals, such as superoxide, peroxyl radicals, hydroxyl radicals, nitric oxide and lipid peroxyl, which process, prevents or delays damage to the cells and tissues (Birben, Sahiner, Sackesen, Erzurum, \& Kalayci, 2012; Kong \& Lin, 2010).Their 
Nutraceutical potential of tomato products after in vitro digestion |SI39

mechanisms of action include scavenging of reactive oxygen and nitrogen free radical species; decreasing the localized oxygen concentration, and therefore reducing molecular oxygen's oxidation potential; metabolizing lipid peroxides to nonradical products; and chelating metal ions to prevent the generation of free radicals (Barzegar, 2012; Madhuri, Qairunnisa, Suresh, Kondam, \& Chandrasekhar, 2014).

A number of studies have established that some fruits, grains and vegetables have antioxidant capacity; this has been attributed principally to their polyphenol and flavonoid contents (Oboh \& Ademosun, 2011; Omoba, Dada, \& Salawu, 2015; Saidu \& Garba, 2011; Salawu et al., 2016; Salawu, Bester, \& Duodu, 2014; Yafang, Gan, \& Jinsong, 2011). Regular intake of antioxidantcontaining foods can reduce the risk of many chronic diseases, such as cardiovascular diseases, heart diseases, diabetes, obesity and certain cancers, and improve the endothelial function and reduce blood pressure (Pellegrino, 2016; Zhang et al., 2015). Phenolic compounds have been reported by many researchers to be present in cereals, fruit and grain crops (Salawu et al., 2014; Shahidi \& Chandrasekara, 2013).

Tomatoes are a concentrated source of phenolic compounds, such as flavonoids and hydroxycinnamic acid derivatives; containing $98 \%$ of the total flavonols in tomato skin as conjugated forms of quercetin and kaempferol (C., F., H., \& Didier, 2011; Hossain, Strezov, Chan, \& Nelson, 2010; Skrovankova, Sumczynski, Mlcek, Jurikova, \& Sochor, 2015). The high content of these compounds in tomato has gained interest due to their apparent multiple biological effects, including free-radical scavenging, metal chelation, inhibition of cellular proliferation, and modulation of enzymatic activity and signal transduction pathways (Vallverdu-Queralt et al., 2011). Among the most prominent phytochemicals in tomatoes are the carotenoids, of which lycopene is most abundant in the ripened fruit, accounting for approximately $80-90 \%$ of the total pigments (Violeta, Trandafir, \& Ionica, 2013). Aside lycopene, tomatoes also contain $\alpha_{-}, \beta-, \gamma_{-}, \delta$ carotene, zeaxanthin and lutein and also neurosporene, phytoene, and phytofluene C. et al. (2011). Lycopene has the capacity to prevent free radical damage to cells caused by reactive oxygen species. Studies have shown that it reduces the susceptibility of lymphocyte DNA to oxidative damage, inactivates $\mathrm{H}_{2} \mathrm{O}_{2}$ and $\mathrm{NO}$ and protects cells from NO induced membrane damage and cell death (Lobo, Patil, Phatak, \& Chandra, 2010; Uttara, Singh, Zamboni, \& Mahajan, 2009). Moreover, lycopene is also the most efficient singlet oxygen quencher with a capacity found to be more than twice of $\beta$-carotene (Shi, Dai, Kakuda, Mittal, \& Xue, 2008). On the other hand, $\beta$-carotene is important due to its pro-vitamin A activity. Apart from carotenoids, tomato is also a source of ascorbic acid, which is an effective scavenger of superoxide, hydrogen peroxide, singlet oxygen and other free radicals (Yafang et al., 2011).

The cholinergic hypothesis of Alzhemier's disease $(\mathrm{AD})$ holds that the degeneration of neurons in the basal forebrain, the associated loss of cholinergic neurotransmission in the cerebral cortex and hippocampus contribute significantly to cognitive deterioration in $\mathrm{AD}$ (Craig, Hong, $\&$ McDonald, 2011). The loss of cholinergic neurons in AD leads to a reduction in the synthesis of the neurotransmitter, acetylcholine (ACh), which has been associated with cognitive functions. This hypothesis has prompted the search for ways to increase ACh in AD patients. There is a need to inhibit the activity of cholinesterases (ChE) to increase the concentration of $\mathrm{ACh}$ needed for cognitive functions. Extracts from some plants such as Lavandula viridis, and some Nigeria green leafy vegetables have been documented to have ChE inhibitory activities (Costa, Gonçalves, Valentão, Andrade, \& Romano, 2013; Oboh \& Ademosun, 2011).

Antioxidants have to be present in some amount in the specific tissue or organ of plant foods to elicit their potential biological properties (Kasote, Katyare, Hegde, \& Bae, 2015). However, the release of antioxidants from complex food materials during digestion will determine their actual biological properties. Thus, the biological extraction of antioxidants within the digestive system might be different from the extracts obtained using organic solvents. There have been reports that antioxidant activity from the chemical extracts of the food material might misjudge the actual antioxidant capacity in the digestive tract (Bhatt \& Patel, 2015). In vitro digestion 
SI40 | Salawu et al.

method measures the bioavailability of the nutrient, which is the amount of the nutrient liberated from the food material during gastrointestinal digestion, which is, in turn, available for absorption in the body (Chandrasekara \& Shahidi, 2012). Therefore, it can be used to evaluate a large number of food systems, which would be costly to analyze for different parameters using human or animal models.

Therefore, the objective of this work is to evaluate the antioxidant and anticholinesterase action of a Nigerian tomato fruit (Early girl) and two different commercially processed tomato paste after a simulated human gastrointestinal digestion.

\section{Materials and Methods}

\section{$2.1 \quad$ Chemicals}

Follin-Ciocalteu's reagent, gallic acid, sodium carbonate, iron (iii) chloride, potassium ferricyanide, trichloroacetic acid, aluminium chloride, potassium acetate, 2,2- diphenyl1-picrylhydrazyl radical and 6-hydroxy-2, 5,7,8-tetramethylchroman-2-carboxylic acid (Trolox), sodium nitroprusside, sulphanilamide, N-(1-Naphthyl-ethyl-diamine-dihydrchloride), orhophosphoric acid, sodium azide, adrenalin, GHS, xanthine oxidase, xanthine, acetylcholine iodide, butyrylcholine iodide were obtained from Sigma chemical company, USA. All other chemicals were obtained from standard chemical suppliers and were of analytical grade, while the water used was glass distilled.

\section{Sample Collection}

Tomato fruit, 'Early girl' (ripe and unripe) and two different types of processed tomato paste (Paste 1 and Paste 2) were bought from Shasha market in Akure, Nigeria. The fresh tomato fruit (ripe and unripe) were identified and authenticated in the Department of Crop, Soil and Pest Management, of the Federal University of Technology, Akure, Nigeria.

\subsection{Sample Treatments and Preparation}

The fresh tomatoes were washed and blended into paste. Both the blended and the commercially processed tomatoes were freeze-dried at the Central Laboratory of Obafemi Awolowo University, Ile-Ife, Nigeria. The freeze-dried samples (ripe tomato fruit, unripe tomato fruit, Paste 1 tomato, Paste 2 Tomato) were divided in to two groups each; the first group was extracted with ethanol, while the second group was subjected to in vitro enzyme ( $\alpha$ - amylase, pespsin, pancreatin) digestion.

\section{Preparation of Ethanolic Extract}

The extraction steps were carried out by soaking $2 \mathrm{~g}$ of each of the lyophilized sample in $40 \mathrm{ml}$ of $96 \%$ ethanol for 24 hours, after which the supernatant was filtered with filter paper No.42 and stored in an amber bottle. This process was repeated by the addition of another $40 \mathrm{ml}$ of $96 \%$ ethanol to the residue for another 24 hours and the supernatant pulled together. The filtrate was stored at $4^{\circ} \mathrm{C}$.

\section{Preparation of Brain and Liver Homogenates for Lipid Peroxidation Assay}

The rats were anesthetized with chloroform and then sacrificed. The cerebral tissue (whole brain) and liver were rapidly isolated, weighed and placed on ice. The tissues were subsequently homogenized in $0.1 \mathrm{M}$ Tris- $\mathrm{HCl} \mathrm{pH} 7.4$ with about ten up and ten down strokes at approximately 1,200 rpm in a Teflon-glass homogenizer. The homogenate was centrifuged for 10 minutes at $3,000 \mathrm{~g}$ to yield a pellet that was discarded and the low-speed supernatant was kept for lipid peroxidation assay, acetylcholinesterase (AChE) and butrylcholineesterase (BuChE) inhibition assay.

\subsection{In vitro Enzymatic Digestion}

The in vitro digestion using sequential enzymatic steps is based on a slightly modified method reported by Ross, Gutierrez-Botero, and Van Am- 
Nutraceutical potential of tomato products after in vitro digestion |SI41

burgh (2013). Two gram of each freeze-dried tomato sample was weighed and dissolved in 40 $\mathrm{mL}$ of distilled water. $300 \mu \mathrm{L}$ of $\alpha$-amylase (32.5 $\mathrm{mg}$ of $\alpha$ - amylase was dissolved in $25 \mathrm{~mL}$ of 1 $\mathrm{mM}$ calcium chloride at $\mathrm{pH} 7$ ) was added to the tubes. The tubes were incubated in a shaking water bath set at $37^{\circ} \mathrm{C}$ for 10 minutes and at 80 strokes/minute. After 10 minutes, the $\mathrm{pH}$ was adjusted to 2 using concentrated $\mathrm{HCl}$. After 30 minutes of incubation in a shaking water bath set at $37^{\circ} \mathrm{C}, 2 \mathrm{mg}$ pepsin, which was dissolved in $1 \mathrm{ML}$ of $0.05 \mathrm{M} \mathrm{HCl}$, was added to the tube. The tubes were then incubated in a shaking water bath set at $37^{\circ} \mathrm{C}$ for 10 minutes and at 80 strokes/minute.

After further 20 minutes of shaking the tubes, the $\mathrm{pH}$ was adjusted to 6 using $\mathrm{NaOH}$. Then, $10 \mathrm{~mL}$ of pancreatin ( $3 \mathrm{~g}$ of pancreatin was dissolved in $20 \mathrm{~mL}$ distilled water) was added, and the tubes were incubated in a shaking water bath set at $37{ }^{\circ} \mathrm{C}$ for 20 minutes. The $\mathrm{pH}$ was adjusted finally to 7.5 using $\mathrm{NaOH}$ (simulating the $\mathrm{pH}$ conditions in the small intestine). Then, the tubes were incubated for 10 minutes in a shaking water bath set at $37{ }^{\circ} \mathrm{C}$. The digested sample was incubated at $100{ }^{\circ} \mathrm{C}$ for 4 minutes to inactivate the enzymes, and the digested sample was then centrifuged for 60 minutes at 3,200 g, and then, the soluble fraction was kept in the refrigerator for antioxidant, anticholinesterase and lipid peroxidation analyses. The insoluble fraction was discarded. An undigested control was also prepared using the same scheme of in vitro digestion but without the enzymes.

\subsection{Antioxidant Indices}

A modified Folin-Ciocalteu method (Berker, Olgun, Ozyurt, Demirata, \& Apak, 2013) and a method reported by Meda, Lamien, Romito, Millogo, and Nacoulma (2005) were used to measure the total phenolic content (TPC) and total flavonoid content (TFC), respectively. Centrifuged ethanol extracts and enzyme digest were reacted with Folin-Ciocalteu phenol reagent and sodium carbonate (20 per cent, w/v for 2 hours) and absorbance was read at $760 \mathrm{~nm}$. Gallic acid was used as a standard and the TPC expressed as mg of gallic acid equivalent (GAE) per gram.
Similarly, the centrifuged ethanol extracts and enzyme digests were reacted with $0.5 \mathrm{~mL}$ ethanol, $50 \mu \mathrm{L}$ of 10 per cent $\mathrm{AlCl}_{3}, 50 \mu \mathrm{L}$ of $1 \mathrm{~mol} \mathrm{~L}^{-1}$ potassium acetate and $1.4 \mathrm{~mL}$ water and allowed to incubate at room temperature for 30 minutes. Thereafter, the absorbance of each reaction mixture was subsequently measured at $415 \mathrm{~nm}$. The TFC was calculated using quercetin as a standard by making use of a seven-point standard curve $(0-100 \mu \mathrm{g} / \mathrm{mL})$. The ferric-reducing properties of the ethanolic extracts and enzyme digests were determined using the method of $\mathrm{Oy}$ aizu (1986), by reacting $1 \mathrm{~mL}$ ethanol extracts and enzyme digest with $1 \mathrm{~mL}$ of $200 \mathrm{mM}$ sodium phosphate buffer ( $\mathrm{pH} \mathrm{6.6)}$ and $1 \mathrm{~mL}$ of 1 percent potassium ferricyanide. The mixture was incubated at $50^{\circ} \mathrm{C}$ for 20 minutes, and then, $1 \mathrm{~mL}$ of 10 percent trichloroacetic acid was added. This mixture was centrifuged at $353 \mathrm{x}$ g for $10 \mathrm{~min}-$ utes. The supernatant $(2 \mathrm{~mL})$ was mixed with an equal volume of water and $0.4 \mathrm{~mL}$ of 0.1 percent ferric chloride. The absorbance was measured at $700 \mathrm{~nm}$. The ferric-reducing antioxidant power was expressed as milligram of ascorbic acid equivalent/gram of the sample. Radical scavenging antioxidant activity of the ethanolic extracts and enzyme digests were determined using the 2, 2-azino-bis-3-thylbenzothiazoline-6-sulphonic acid (ABTS) radical scavenging assay according to Awika, Rooney, Wu, Prior, and CisnerosZevallos (2003); 1, 1 diphenyl-2-picrylhdrazyl $(\mathrm{DPPH})$ radical scavenging assay according to the method of Brand-Williams, Cuvelier, and Berset (1995); Hydroxyl radical scavenging assay by Halliwell and Gutteridge (1999) and nitric oxide radical scavenging assay by Griess reaction using the method of Sangameswaran, Balakrishnan, Deshraj, and Jayakar (2009). Trolox was used as a standard for ABTS and DPPH antiradical assay, and the values reported as $\mu \mathrm{mol}$ trolox equivalent anti-oxidant capacity per gram ( $\mu \mathrm{mol} \mathrm{TE} / \mathrm{g})$. Ascorbic acid was used as the standard for nitric oxide radical assay and the values were expressed as percentage inhibition.

\subsection{Lipid Peroxidation Assay}

The ability of the ethanolic extract and the in vitro-digested samples to inhibit lipid peroxida- 
tion was assessed using a modified method presented in the study by Ohkawa, Ohishi, and Yagi (1979). The homogenates obtained (100 $\mu \mathrm{L})$ from white rat's liver and brain were incubated with (or without for the blank); $50 \mu \mathrm{L}$ of freshly prepared $0.071 \mathrm{mM} \mathrm{FeSO}_{4}, 30 \mu \mathrm{L} 100$ $\mathrm{mM}$ Tris-HCl (pH 7.4) and ethanol extract/in vitro-digested samples $(0-100 \mu \mathrm{L})$, together with an appropriate volume of deionized water, to give a total volume of $300 \mu \mathrm{L}$ were then incubated at $37{ }^{\circ} \mathrm{C}$ for 1 hour. The color reaction was carried out by adding $300 \mu \mathrm{L}$ of 8.1 percent $\mathrm{w} / \mathrm{v}$ sodium dodecyl sulphate, $500 \mu \mathrm{L}$ of 0.15 percent $\mathrm{v} / \mathrm{v}$ acetic acid solution $(\mathrm{pH} 3.4)$ and $500 \mu \mathrm{L}$ of 0.6 percent $\mathrm{w} / \mathrm{v}$ thiobarbithuric acid. The absorbance was read after cooling the tubes at a wavelength of $532 \mathrm{~nm}$. As control, the homogenate was peroxidized with $0.071 \mathrm{mM}$ $\mathrm{FeSO}_{4}$ without the in vitro enzyme-digested samples or ethanolic extracts. A blank containing other reagents except $\mathrm{FeSO}_{4}$, homogenate and the extracts was also prepared.

\subsection{Acetylcholine and Butrylcholine Esterase Inhibitory Activity Assay}

AChE and BuChE inhibitory activity were measured by the spectrophotometric method developed by Lin, Liu, Lin, and Wu (2004) with slight modifications, using acetylcholine iodide and butrylcholine iodide as substrates, respectively. The rate of production of thiocholine is determined by the continuous reaction of the thiol with 5, 5-dithiobis-2-nitrobenzoate (DTNB) ion to produce the yellow anion of 5-thio-2-nitrobenzoic acid. Briefly, $1 \mathrm{~mL}$ of $10 \mathrm{mM}$ DTNB dissolved in $10 \mathrm{mM}$ sodium phosphate buffer $(\mathrm{pH}$ 7.0) was added to $0.6 \mathrm{~mL}$ of distilled water. The brain homogenate, acting as the enzyme source $(0.1 \mathrm{~mL})$ and the digested sample/ethanol extract $(0.1 \mathrm{~mL})$ was then added to the mixture and incubated for 2 minutes at $25{ }^{\circ} \mathrm{C}$ before 0.2 $\mathrm{mL}$ of $8 \mathrm{mM}$ acetylcholine iodide (substrate) was added. The absorbance of the mixture was read at $412 \mathrm{~nm}$ at intervals of 30 seconds for 5 minutes immediately after the substrate was added. For the control, $0.1 \mathrm{~mL}$ of brain homogenate (enzyme source) was added to $1 \mathrm{~mL}$ of $10 \mathrm{mM}$ DTNB dis- solved in $10 \mathrm{mM}$ sodium phosphate buffer $(\mathrm{pH}$ 7.0) and $0.7 \mathrm{~mL}$ of distilled water. The mixture was incubated at $25^{\circ} \mathrm{C}$ for 2 minutes before 0.2 $\mathrm{mL}$ of $8 \mathrm{mM}$ of acetylcholine iodide was added and the absorbance was taken immediately. The distilled water $(0.1 \mathrm{~mL})$ and $10 \mathrm{mM}$ DTNB (1 $\mathrm{mL}$ ) were used as blank. The procedure was repeated using $8 \mathrm{mM}$ butrylcholine iodide as the substrate. The results were expressed in $\mu \mathrm{mol}$ $\min ^{-1} \mathrm{mg}$ protein ${ }^{-1}$ using a molar extinction coefficient of $13.6 \times 10^{3} \mathrm{M}^{-1} \mathrm{~cm}^{-1}$.

\subsection{Statistical Analysis}

All the analyses were run in triplicates. Results were then computed using Microsoft Excel software (Microsoft Corporation, Redmond, WA) and followed by one-way Anova Tukey Multiple Range Test (TMRT) to compare the means that showed significant variation by using graph pad for windows. The significance level was set at $\mathrm{p}<0.05$.

\section{Results and Discussions}

\section{$3.1 \quad$ Results}

\section{Antioxidant Indices}

The result of the total phenolic content (TPC), is as presented on Table 1.The results revealed a higher TPC (mg GAE/g sample) for all in vitro enzyme-digested tomato samples (ripe tomato: 61.08; processed tomato paste 2: 60.36; processed tomato paste 1: 56.02; unripe tomato: 38.97 ) than the ethanolic extracts (ripe tomato: 35.59 ; processed tomato paste 2: 30.28 ; processed tomato paste 1: 29.99; unripe tomato: 14.91). Thus, the maximum amount of total phenolic compounds was released during in vitro digestion process because of the activity of the enzymes ( $\alpha$-amylase, pepsin and pancreatin) of the gastrointestinal tract. The result further showed that the TPC of in vitro digested ripe tomato (61.08 $\mathrm{mg}$ GAE $\mathrm{g}^{-1}$ sample) was higher than in vitro digested unripe sample $(38.97 \mathrm{mg}$ GAE $\mathrm{g}^{-1}$ sample) and that TPC of ripe unprocessed tomato was higher than the processed tomato (both paste 2 and paste 1 ). 
Nutraceutical potential of tomato products after in vitro digestion |SI43

The total flavonoid content (mg quercetin equivalent/g of sample) of ethanolic extracts and in vitro enzyme digested samples of tomato fruits (ripe and unripe) and commercially processed tomato paste 2 and paste 1 is as shown in Table 1. The result also showed that the in vitro enzyme digested samples have higher total flavonoid content (ripe tomato: 50.86; processed tomato paste 2: 43.95; processed tomato paste 1: 29.47; unripe tomato: 25.06) than the ethanolic extracts (ripe tomato: 21.25; processed tomato paste 2: 18.06; processed tomato paste 1:10.62; unripe tomato: 10.01). The result also revealed that processed tomato paste 2 has higher TFC compared to paste 1.

Similarly, the result of ferric reducing antioxidant power ( $\mathrm{mg}$ ascorbic acid equivalent/g of sample) of ethanolic extracts and, in vitro enzyme digested samples of tomato fruits (ripe and unripe) and commercially processed tomato paste 2 and paste 1 (Table 1 ), revealed that the digested samples have higher reducing power (ripe tomato: 19.89; processed tomato paste 2: 18.70; processed tomato paste 1: 12.86; unripe tomato:10.36) than the ethanolic extracts (ripe tomato: 11.98; tomato paste 2: 11.40; tomato paste 1: 7.39; unripe tomato: 1.70). Similar to what was observed in the total phenolic and flavonoid estimation, in vitro digested ripe tomato showed higher reducing power than digested unripe tomato. In addition, higher reducing power was recorded in ripe tomato compared to the processed tomato in both ethanolic extracts and digested samples.

The result of the radical scavenging potentials of the in vitro enzyme digested tomato samples displayed a higher radical scavenging activities DPPH*$^{*}, \mathrm{ABST}^{+}{ }^{+}, \mathrm{NO}^{*}$ and $\mathrm{OH}^{*}$ ) compared to the ethanolic extracts. In addition, radical scavenging activities (DPPH', ABTS ${ }^{+}, \mathrm{NO} \cdot$ and $\mathrm{OH})$ was higher in digested ripe tomato than in digested processed tomato, while processed tomato paste 2 revealed higher radical scavenging activities than tomato paste 1.

\section{Antioxidant Enzyme Assay}

In this current study, the ethanolic extracts and in vitro digested samples revealed enhanced activities of the antioxidant enzymes (GPx, GSH,
SOD and CAT) in a manner similar to the trends observed in the phenolic content estimation and radical scavenging activities 3 . The activities of the enzymes were enhanced to a higher degree after simulated in vitro digestion of both the tomato fruit and commercially processed tomato product. The digested ripe tomato fruit reveal higher activities of the antioxidant enzyme compared to processed tomato paste and unripe tomato fruit. Tomato paste 2 also showed higher enhanced activities of the enzymes than tomato paste 1.

\section{Lipid Peroxidation Assay}

Both the ethanolic extracts and in vitro digested samples of tomato (fruit and paste) showed potential for inhibition of lipid peroxidation 2. Similarly, in vitro digested samples revealed higher inhibitory action against lipid oxidation compared to ethanolic extracts. Higher inhibitory action was also recorded for digested ripe tomato while the least inhibition action was observed in unripe tomato. The result also showed that processed tomato paste 2 has higher inhibition action than tomato paste 1 .

\section{Acetylcholine and Butrylcholine Esterase Inhibitory Activity Assay}

The result obtained from the cholinesterase (AChE and BuChE) inhibitory action of tomato fruit and paste revealed that in vitro enzyme digested and ethanolic extracts of tomato fruit and paste samples possessed appreciable potential of inhibiting $\mathrm{AChE}$ and BuChE activity (Figures 1 and 2). The in vitro digested samples displayed higher inhibitory action compared to the ethanolic extracts. The highest \% inhibitory action against $\mathrm{AChE}$ and BuChE activity was recorded for digested ripe tomato followed by tomato paste 2 , while the least \% inhibition was observed in unripe tomato. Furthermore, processed tomato paste 2 tomato had higher inhibition potential than processed tomato paste 1 .

\subsection{Discussion}

The observed higher phenolic content in the in vitro digested tomato samples is in agreement 
SI44 | Salawu et al.

Table 1: Antioxidant Indices of tomato fruit (ripe and unripe) and paste (paste 2 and paste 1)

\begin{tabular}{llllllll}
\hline Samples & $\begin{array}{l}\text { TPC } \\
(\mathrm{mg} \mathrm{GAE} / \mathrm{g})\end{array}$ & $\begin{array}{l}\text { TFC } \\
(\mathrm{mg} \mathrm{QE} / \mathrm{g})\end{array}$ & $\begin{array}{l}\text { FRAP } \\
(\mathrm{mg} \mathrm{AAE} / \mathrm{g})\end{array}$ & $\begin{array}{l}\text { DPPH } \\
(\mu \mathrm{mol} \mathrm{TE} / \mathrm{g})\end{array}$ & $\begin{array}{l}\text { ABTS } \\
(\mu \mathrm{mol} \mathrm{TE} / \mathrm{g})\end{array}$ & $\begin{array}{l}\text { NO } \\
(\% \text { Inhibition })\end{array}$ & $\begin{array}{l}\text { OH } \\
(\% \text { Inhibition })\end{array}$ \\
\hline $\mathrm{RT}$ & $35.59 \pm 0.09^{d}$ & $21.25 \pm 1.01^{c}$ & $11.98 \pm 0.01^{d}$ & $50.03 \pm 0.40^{d}$ & $89.86 \pm 0.00^{c}$ & $58.67 \pm 0.60^{c}$ & $18.11 \pm 0.90^{d}$ \\
$\mathrm{UT}$ & $14.91 \pm 0.05^{a}$ & $10.01 \pm 0.35^{a}$ & $01.70 \pm 0.01^{a}$ & $34.14 \pm 0.20^{a}$ & $83.40 \pm 0.40^{a}$ & $48.36 \pm 0.60^{a}$ & $0.47 \pm 0.18^{a}$ \\
P1 & $29.99 \pm 0.03^{b}$ & $10.62 \pm 0.62^{a}$ & $07.40 \pm 0.00^{b}$ & $37.04 \pm 0.35^{b}$ & $87.64 \pm 0.60^{b}$ & $49.24 \pm 0.11^{a}$ & $10.57 \pm 2.09 \mathrm{c}$ \\
P2 & $30.28 \pm 0.05^{c}$ & $18.06 \pm 0.30^{b}$ & $11.40 \pm 0.21^{d}$ & $42.13 \pm 0.12^{c}$ & $89.38 \pm 0.60^{c}$ & $53.48 \pm 0.00^{b}$ & $10.60 \pm 0.09^{c}$ \\
DRT & $61.08 \pm 0.30^{f g}$ & $50.86 \pm 0.41^{g}$ & $19.89 \pm 0.00^{g}$ & $71.90 \pm 0.63^{g}$ & $95.49 \pm 0.14^{e}$ & $69.06 \pm 0.51^{f}$ & $35.71 \pm 0.18^{g}$ \\
DUT & $38.97 \pm 0.55^{e}$ & $25.06 \pm 0.00^{d}$ & $10.36 \pm 0.00^{c}$ & $50.75 \pm 0.81^{d}$ & $89.86 \pm 0.14^{c}$ & $60.75 \pm 0.17^{d}$ & $06.99 \pm 0.73^{b}$ \\
DP1 & $56.02 \pm 0.05^{f}$ & $29.47 \pm 0.66^{e}$ & $12.86 \pm 0.02^{e}$ & $63.34 \pm 0.37^{e}$ & $93.75 \pm 0.00^{d}$ & $64.67 \pm 0.37^{e}$ & $26.87 \pm 0.73^{e}$ \\
DP2 & $60.36 \pm 0.35^{f g}$ & $43.95 \pm 0.66^{f}$ & $18.70 \pm 0.01^{f}$ & $65.06 \pm 0.27^{f}$ & $94.86 \pm 0.60^{e}$ & $67.55 \pm 0.06^{f}$ & $32.43 \pm 0.91^{f}$ \\
\hline
\end{tabular}

Values represent mean \pm standard deviation of triplicate experiments. Values with different superscripts in the same column differ significantly $(\mathrm{p}<0.05)$. Abbreviations: $\mathrm{RT}=$ Ripe Tomatoes; UT= Unripe Tomatoes;

P1= Paste 1 Tomatoes; P2= Paste 2 Tomatoes; DRT = Digested Ripe Tomatoes; DUT = Digested Unripe Tomatoes; $\mathrm{DPT}=$ Digested Paste 2 Tomatoes; DGT $=$ Digested Paste 1 Tomatoes; GAE $=$ Gallic Acid Equivalent; $\mathrm{QE}=$ Quercetin Equivalent; $\mathrm{AAE}=$ Ascorbic Acid Equivalent; $\mathrm{TE}=$ Trolox equivalents.

Table 2: IC50 values of ethanolic extract and in vitro digested tomato fruit and paste on iron and sodium nitropuside induced lipid oxidation $(\mathrm{mg} / \mathrm{g})$

\begin{tabular}{lllll}
\hline \multirow{2}{*}{ Samples } & \multicolumn{2}{c}{$\mathrm{Fe}^{2+}$ induced } & \multicolumn{2}{c}{ SNP induced } \\
& Brain & Liver & Brain & Liver \\
\hline RT & $108.3 \pm 0.02^{d}$ & $70.00 \pm 0.29^{d}$ & $108.0 \pm 1.01^{d}$ & $60.91 \pm 0.43^{b}$ \\
UT & $183.2 \pm 0.44^{h}$ & $119.6 \pm 1.34^{h}$ & $183.2 \pm 0.19^{h}$ & $125.3 \pm 1.63^{g}$ \\
P1 & $174.6 \pm 0.16^{g}$ & $78.42 \pm 0.34^{f}$ & $124.6 \pm 0.51^{g}$ & $80.49 \pm 1.56^{e}$ \\
P2 & $161.3 \pm 0.08^{f}$ & $72.47 \pm 1.02^{e}$ & $116.2 \pm 1.56^{e}$ & $65.05 \pm 0.00^{c}$ \\
DRT & $69.51 \pm 0.09^{a}$ & $53.21 \pm 0.45^{a}$ & $79.51 \pm 0.00^{a}$ & $52.01 \pm 0.04^{a}$ \\
DUT & $126.1 \pm 1.02^{e}$ & $95.09 \pm 0.69^{g}$ & $122.1 \pm 0.97^{f}$ & $86.54 \pm 1.02^{f}$ \\
DP1 & $83.13 \pm 0.06^{c}$ & $66.19 \pm 0.75^{c}$ & $83.13 \pm 0.04^{b}$ & $76.81 \pm 0.56^{d}$ \\
DP2 & $76.42 \pm 0.05^{b}$ & $63.73 \pm 1.34^{b}$ & $94.42 \pm 0.68^{c}$ & $61.01 \pm 1.01^{b}$ \\
\hline
\end{tabular}

Values represent mean \pm standard deviation of triplicate experiments. Values with different superscripts in the same column differ significantly $(\mathrm{p}<0.05)$. Abbreviation: RT= Ripe Tomatoes; UT $=$ Unripe Tomatoes; P1= Paste 1 Tomatoes; P2= Paste 2 Tomatoes; DRT= Digested Ripe Tomatoes; DUT $=$ Digested Unripe Tomatoes; DPT $=$ Digested Paste 2 Tomatoes; DGT= Digested Paste 1 Tomatoes 
Nutraceutical potential of tomato products after in vitro digestion |SI45

Table 3: Effect of ethanolic extract and in vitro digested samples of tomato fruit and paste on antioxidant enzyme activities

\begin{tabular}{lllll}
\hline Samples & $\begin{array}{l}\text { GSH } \\
(\mathrm{U} / \mathrm{mL})\end{array}$ & $\begin{array}{l}\text { GPX } \\
(\mathrm{U} / \mathrm{mL})\end{array}$ & $\begin{array}{l}\text { SOD } \\
(\mathrm{U} / \mathrm{mL})\end{array}$ & $\begin{array}{l}\text { CATALASE } \\
(\mathrm{U} / \mathrm{mL})\end{array}$ \\
\hline RT & $8.54 \pm 0.65^{c}$ & $14.6 \pm 0.18^{e}$ & $3.14 \pm 0.02^{c}$ & $2.49 \pm 0.09^{c}$ \\
$\mathrm{UT}$ & $5.39 \pm 0.26^{a}$ & $1.68 \pm 0.11^{a}$ & $0.68 \pm 0.13^{a}$ & $1.10 \pm 0.02^{a}$ \\
P1 & $6.43 \pm 0.16^{b}$ & $2.83 \pm 0.9^{b}$ & $1.64 \pm 0.03^{b}$ & $1.57 \pm 0.11^{b}$ \\
P2 & $6.63 \pm 0.08^{b}$ & $8.38 \pm 0.06^{d}$ & $3.12 \pm 0.04^{c}$ & $2.15 \pm 0.47^{b}$ \\
DRT & $10.68 \pm 0.50^{e}$ & $34.3 \pm 0.02^{h}$ & $6.04 \pm 0.02^{e}$ & $5.15 \pm 0.14^{d}$ \\
DUT & $5.78 \pm 0.65^{a}$ & $6.62 \pm 1.98^{c}$ & $1.46 \pm 0.10^{b}$ & $1.11 \pm 0.01^{a}$ \\
DP1 & $9.24 \pm 0.17^{d}$ & $17.30 \pm 0.75^{f}$ & $3.27 \pm 0.00^{c}$ & $2.61 \pm 0.23^{b}$ \\
DP2 & $9.94 \pm 0.13^{d}$ & $22.87 \pm 0.08^{g}$ & $4.06 \pm 0.02^{d}$ & $2.67 \pm 0.25^{b}$ \\
\hline
\end{tabular}

Values represent mean \pm standard deviation of triplicate experiments. Values with different superscripts in the same column differ significantly $(\mathrm{p}<0.05)$ Abbreviation: $\mathrm{RT}=$ Ripe Tomatoes; $\mathrm{UT}=$ Unripe

Tomatoes; P1= Paste 1 Tomatoes; $\mathrm{P} 2=$ Paste 2 Tomatoes; DRT $=$ Digested Tomatoes; DUT $=$ Digested Unripe Tomatoes; DP2 $=$ Digested

Paste 2 Ripe Tomatoes; DP1= Digested Paste 1 Tomatoes; GSH=

Glutathion; $\mathrm{PX}=$ Glutathion peroxidase; $\mathrm{SOD}=$ Superoxide dismutase.

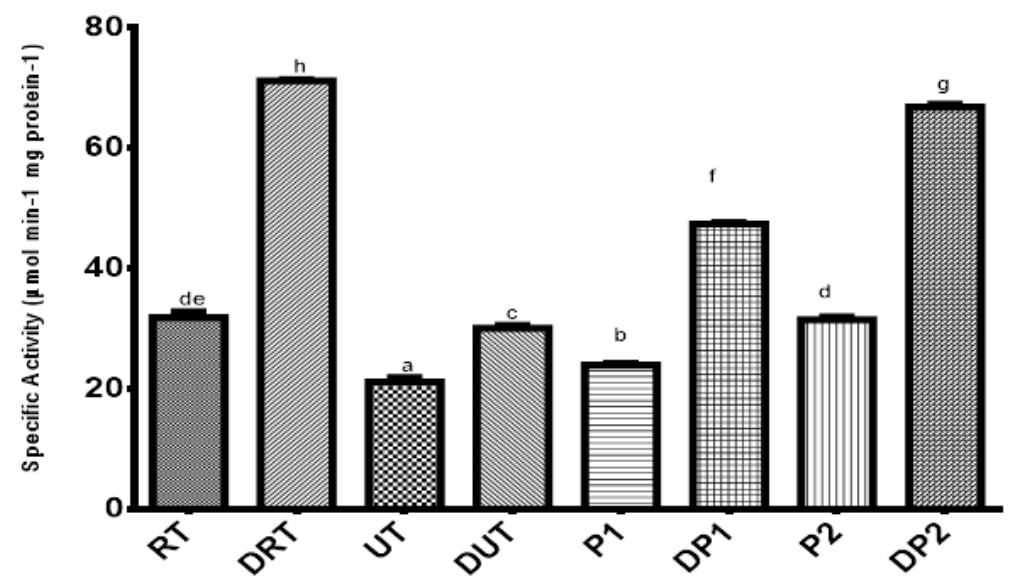

Figure 1: Acetylcholinesterase Inhibitory activity of in vitro digested tomato fruit and paste. Values are given as mean $\pm \mathrm{SE}$ of independent experiments performed in triplicate. Bars with different letters are significantly different $(\mathrm{p}<0.05)$ by Tukey Test. Abbreviation: RT= Ripe Tomatoes; UT= Unripe Tomatoes; P1= Paste 1 Tomatoes; P2= Paste 2 Tomatoes; DRT= Digested Ripe Tomatoes; DUT= Digested Unripe Tomatoes; DPT $=$ Digested Paste 2 Tomatoes; DGT $=$ Digested Paste 1 Tomatoes 
SI46 | Salawu et al.

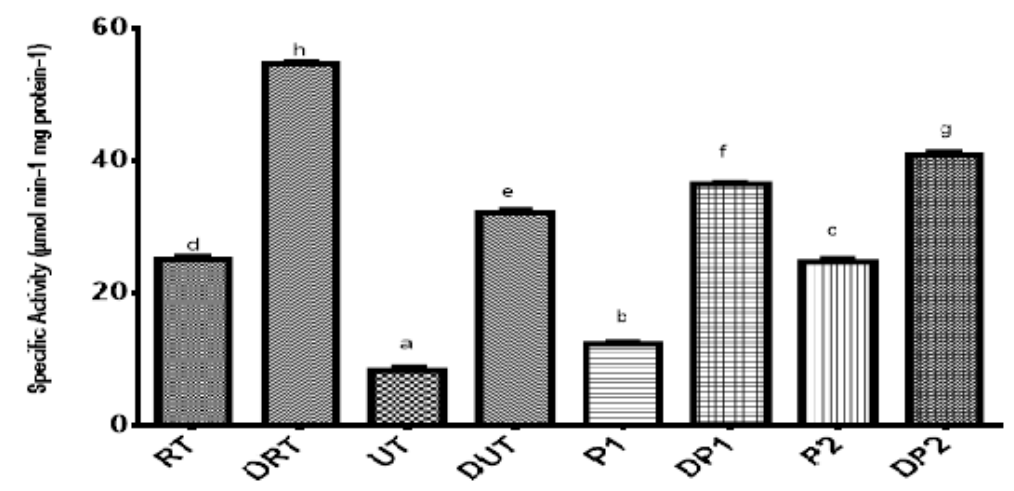

Figure 2: Butyrylcholinesterase Inhibitory of in vitro digested tomato fruit and paste. Values are given as mean $\pm \mathrm{SE}$ of independent experiments performed in triplicate. Bars with different letters are significantly different $(\mathrm{p}<0.05)$ by Tukey Test. Abbreviation: RT= Ripe Tomatoes; UT $=$ Unripe Tomatoes; P1= Paste 1 Tomatoes; P2= Paste 2 Tomatoes; DRT= Digested Ripe Tomatoes; DUT= Digested Unripe Tomatoes; DPT $=$ Digested Paste 2 Tomatoes; DGT $=$ Digested Paste 1 Tomatoes

with a previous report of Tagliazucchi, Verzelloni, Bertolini, and Conte (2010), which suggested that digestion might be a determinant factor in the release of nutritionally relevant compounds from the food matrix. The result further showed that the TPC of in vitro digested ripe

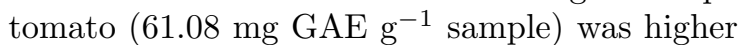
than that of the digested unripe sample (38.97 mg TAE $g^{-1}$ sample). The observed higher TPC in enzyme digested ripe tomato may be associated with a considerable accumulation of lycopene in ripped tomato, which is due to the enhanced enzymatic activity of phytoene synthase I that causes a massive production of lycopene precursors in ripening tomato fruits (Fraser, Enfissi, \& Bramley, 2009). The observed higher TPC of ripe unprocessed tomato compared with the processed tomato (both paste 2 and paste 1), may be ascribed to the different processing methods. This is in correlation with the work of Anese, Mirolo, Beraldo, and Lippe (2013), where it was reported that non-thermal processing seems to have an adverse effect on bioaccessibility of lycopene. For example, the loss of cell integrity observed with increasing ultrasonication time was accompanied by a decrease in lycopene bio-accessibility.

The observed high flavonoid content of the in vitro digested tomato fruit and pastes compared to the ethanolic extract is in agreement with the report of Salawu, Ajiboye, Akindahunsi, and Boligon (2017), where higher flavonoid content were recorded for the in vitro digested white and yellow bitter yams compared to their raw counterparts. This observation might be due to the breakdown of the insoluble fiber matrix of both bitter yam varieties thereby making its flavonoids more accessible for further breakdown by the enzymes of gastro intestinal tract. Ripe digested sample have a higher TFC than the digested processed samples. Ranilla, Genovese, and Lajolo (2007) mentioned that cooking time, temperature, soaking and draining can significantly reduce antioxidant activity of plants. This is also in agreement with the report of Fawole and Opara (2013), it was suggested that naturally occurring flavonoid could be obviously lost during processing and storage, which could affect the overall antioxidant and nutritional value after post-harvest treatment. The observed high flavonoid content in tomato paste 2 compared to paste 1 might be due to the varietal differences in the tomato fruits used in the production of tomato paste 1 and tomato paste 2 and the processing methods. Macheix, Fleuriet, and Billot (1990) suggested that genetic control is the primary factor in determining phenols in fruits and vegetables, their level may be affected by environmental condi- 
tions, such as light, temperature and processing methods.

The ferric reducing antioxidant power (FRAP) of a compound may serve as an important indicator of its potential antioxidants activity (Liu et al., 2013). The observed higher FRAP in the in vitro enzyme digested samples is in agreement with the work of Saura-Calixto and Goni (2006), who reported that in vitro enzyme digested plant yield a higher reducing power that than organic extracts. The observed high reducing power in ripe tomato for both ethanolic extracts and in vitro digested samples compared to commercially processed tomato pastes may be attributed to various processing steps of the tomato paste. This is in agreement with the report of Szydlowska-Czerniak, Trokowski, Karlovits, and Szlyk (2011), where it was reported that ferric reducing antioxidant power was decreased by $41 \%$ during thermal processing of palm oil.

Most plant foods are rich sources of free radical scavenging molecules and other metabolites, which are rich in antioxidant activity (Nimse \& Pal, 2015). The observed high radical scavenging activities (DPPH', $\mathrm{ABST}^{+}{ }^{+}, \mathrm{NO} \cdot$ and $\left.\cdot \mathrm{OH}\right)$ the in vitro enzyme digested tomato samples compared to the ethanolic extracts is in agreement with the work of Hachibamba, Dykes, Awika, Minnaar, and Duodu (2013), where it was found that the TPC and radical scavenging properties of cowpea was increased with simulated in vitro enzyme digestion. The observed high radical scavenging activities in digested ripe tomato fruits compared to the commercially processed tomato pastes is likely to be as a result of heat processing to attain final solid level. Longer processing times, required to achieve the desired final solids levels, may be associated with increased losses. Other studies have also shown thermal processing to decrease significantly the TPC, anthocyanin content, and antioxidant activity (Hiemori, Koh, \& Mitchell, 2009).

It has been found that a substantial link exists between free radicals and more than sixty different health conditions, including the aging process, cancer, diabetes, Alzheimer's disease, strokes, heart attacks and atherosclerosis. By reducing exposure to free radicals and increasing the intake of antioxidant enzyme rich foods or antioxidant enzyme supplements, our body's potential to reducing the risk of free radical related health problems is made more palpable (Worthington Enzyme Manual, 2009). The enhanced antioxidant enzyme parameters in the presence of the ethanolic extracts and in vitro digested tomato samples in a manner similar to the trends observed in the phenolic content estimate and radical scavenging assays is in agreement Jalili, Ilkhanipour, Heydari, Farshid, and Salehi (2007), and Ergüder and Durak (2006). These authors, confirmed that administration of lycopene at 100, 200 and $300 \mathrm{mg} / \mathrm{kg}$ doses decreased the level of oxidant parameters (MDA) and significantly increased blood and gastric antioxidant parameters (SOD, CAT and GSH-Px), and suggested that lycopene may reduce oxidative injury of gastric cancer rats partly through stimulating antioxidant enzyme activities. Antioxidant enzymes are, therefore, critical for maintaining optimal cellular and systemic health and well-being.

Both the ethanolic extracts and in vitro digested samples of tomato (fruit and paste) showed potential of inhibiting lipid oxidation. The result correlate with the work of Luo and $\mathrm{Wu}$ (2011), where it was reported that lycopene treatment in rats, with induced gastric cancer significantly ameliorated an increased MDA level at the end of the experiment. Since flavonoid represent the major component of the total phenolic content in tomato (Toor \& Savage, 2005), hence, the flavonoids, lycopene and other phenolic compounds present in tomato fruit and paste may be responsible for their ability to inhibit lipid peroxidation.

In recent years, the search for inhibitors of cholinesterases has grown in interest, since these enzymes are associated with Alzheimer's disease, senile dementia, ataxia, myasthenia gravis, and Parkinson's disease among others (Mukherjee, Kumar, Mal, \& Houghton, 2007; Vinholes et al., 2011). Plant alkaloids are best known for inhibiting cholinesterase enzymes, however, recent reports have indicated new classes of cholinesterase inhibiting phytochemicals such as coumarins, flavonols, terpenoids, and especially monoterpenes that are relevant antioxidant phytochemicals (Katalinic, Bosak, \& Kovarik, 2014; Szwajgier, 2014). Hence, the observed anticholinesterase action in both ethanolic extracts 
and in vitro enzyme digest of the studied tomato samples could be ascribed to the constituent phytochemicals in tomato fruits and commercially processed tomato pastes.

\section{Conclusion}

The result of this investigation showed that the studied tomato fruit and pastes possess a substantial level of antioxidant and anticholinesterase activities after the simulated human gastrointestinal digestion, with the ripe tomato fruit ranking high. This by implication suggest that the health promoting phytoconstituents of the tomato fruit and pastes would be readily bio-available after passing through the gastrointestinal digestive tract and therefore could be harnessed as functional food.

\section{References}

Anese, M., Mirolo, G., Beraldo, P., \& Lippe, G. (2013). Effect of ultrasound treatments of tomato pulp on microstructure and lycopene in vitro bioaccessibility. Food Chemistry, 136(2), 458-463. doi:10.1016/j. foodchem.2012.08.013

Awika, J. M., Rooney, L. W., Wu, X. L., Prior, R. L., \& Cisneros-Zevallos, L. (2003). Screening methods to measure antioxidant activity of sorghum (sorghum bicolor) and sorghum products. Journal of Agricultural and Food Chemistry, 51(23), 6657-6662. doi:10.1021/jf034790i

Barzegar, A. (2012). The role of electron-transfer and $\mathrm{H}$-atom donation on the superb antioxidant activity and free radical reaction of curcumin. Food Chemistry, 135(3), 13691376. doi:10.1016/j.foodchem.2012.05.070

Berker, K. I., Olgun, F. A. O., Ozyurt, D., Demirata, B., \& Apak, R. (2013). Modified folin-ciocalteu antioxidant capacity assay for measuring lipophilic antioxidants. Journal of Agricultural and Food Chemistry, 61(20), 4783-4791. doi:10.1021/jf400249k

Bhatt, A., \& Patel, V. (2015). Antioxidant potential of banana: Study using simulated gastrointestinal model and conventional ex- traction. Indian Journal of Experimental Biology, 53(7), 457-461.

Birben, E., Sahiner, U. M., Sackesen, C., Erzurum, S., \& Kalayci, O. (2012). Oxidative stress and antioxidant defense. World Allergy Organization Journal, 5(1), 9-19. doi:10.1097/WOX.0b013e3182439613

Brand-Williams, W., Cuvelier, M., \& Berset, C. (1995). Use of a free radical method to evaluate antioxidant activity. $L W T$ - Food Science and Technology, 28(1), 25-30. doi:10. 1016/S0023-6438(95)80008-5

C., R. R., F., E. S. A., H., P. S., \& Didier, M. (2011). Anti-oxidant properties and other functional attributes of tomato: An overview. International Journal of Food and Fermentation Technology, 1(2), 139148. Retrieved from https : / / www . indianjournals.com/ijor . aspx? target=ijor: ijfft\&volume $=1 \&$ issue $=2 \&$ article $=001$

Chandrasekara, A., \& Shahidi, F. (2012). Bioaccessibility and antioxidant potential of millet grain phenolics as affected by simulated in vitro digestion and microbial fermentation. Journal of Functional Foods, 4(1), 226-237. doi:10.1016/j.jff.2011.11.001

Costa, P., Gonçalves, S., Valentão, P., Andrade, P. B., \& Romano, A. (2013). Accumulation of phenolic compounds in in vitro cultures and wild plants of lavandula viridis l'hér and their antioxidant and anticholinesterase potential. Food and Chemical Toxicology, 57, 69-74. doi:https://doi. org/10.1016/j.fct.2013.03.006

Craig, L. A., Hong, N. S., \& McDonald, R. J. (2011). Revisiting the cholinergic hypothesis in the development of alzheimer's disease. Neuroscience \& Biobehavioral Reviews, 35(6), 1397-1409. doi:10.1016/j . neubiorev.2011.03.001

Ergüder, I., \& Durak, I. (2006). Effects of computer use on human salivary oxidant/antioxidant status. OnLine Journal of Biological Sciences, 6. doi:10 . 3844/ ojbsci.2006.14.17

Fawole, O. A., \& Opara, U. L. (2013). Effects of storage temperature and duration on physiological responses of pomegranate fruit. Industrial Crops and Products, 47, 300309. doi:10.1016/j.indcrop.2013.03.028 
Nutraceutical potential of tomato products after in vitro digestion |SI49

Fraser, P. D., Enfissi, E. M., \& Bramley, P. M. (2009). Genetic engineering of carotenoid formation in tomato fruit and the potential application of systems and synthetic biology approaches. Archives of Biochemistry and Biophysics, 483(2), 196-204. Recent Achievements of Carotenoid Science and Technology. doi:10.1016/j.abb.2008. 10.009

Hachibamba, T., Dykes, L., Awika, J., Minnaar, A., \& Duodu, K. G. (2013). Effect of simulated gastrointestinal digestion on phenolic composition and antioxidant capacity of cooked cowpea (vigna unguiculata) varieties. International Journal of Food Science and Technology, 48(12), 2638-2649. doi:10.1111/ijfs.12260

Halliwell, B., \& Gutteridge, J. M. C. (1999). Free radicals in biology and medicine. New York: Oxford University Press.

Hiemori, M., Koh, E., \& Mitchell, A. E. (2009). Influence of cooking on anthocyanins in black rice (oryza sativa l. japonica var. sbr). Journal of Agricultural and Food Chemistry, 57(5), 1908-1914. doi:10 . $1021 /$ jf803153z

Hossain, M. K., Strezov, V., Chan, K. Y., \& Nelson, P. F. (2010). Agronomic properties of wastewater sludge biochar and bioavailability of metals in production of cherry tomato (lycopersicon esculentum). Chemosphere, 78(9), 1167-1171. doi:10.1016/j . chemosphere.2010.01.009

Jalili, S., Ilkhanipour, M., Heydari, R., Farshid, A. A., \& Salehi, S. (2007). The effects of vitamin e on endosulfan-induced oxidative stress in rat heart. Pakistan Journal of $\mathrm{Nu}$ trition, 6(4), 375-380.

Kasote, D. M., Katyare, S. S., Hegde, M. V., \& Bae, H. (2015). Significance of antioxidant potential of plants and its relevance to therapeutic applications. International Journal of Biological Sciences, 11(8), 982991. doi:10.7150/ijbs.12096

Katalinic, M., Bosak, A., \& Kovarik, Z. (2014). Flavonoids as inhibitors of human butyrylcholinesterase variants. Food Technology and Biotechnology, 52(1, SI), 64-67.

Kong, Q., \& Lin, C.-l. G. (2010). Oxidative damage to RNA: Mechanisms, consequences, and diseases. Cellular and Molecular Life Sciences, 67(11), 1817-1829. doi:10.1007/ s00018-010-0277-y

Lin, G., Liu, Y. C., Lin, Y. F., \& Wu, Y. G. (2004). Ortho effects in quantitative structure-activity relationships for acetylcholinesterase inhibition by aryl carbamates. Journal of Enzyme Inhibition and Medicinal Chemistry, 19(5), 395-401. doi:10.1080/14756360410001733694

Liu, Y., Pukala, T. L., Musgrave, I. F., Williams, D. M., Dehle, F. C., \& Carver, J. A. (2013). Gallic acid is the major component of grape seed extract that inhibits amyloid fibril formation. Bioorganic 83 Medicinal Chemistry Letters, 23(23), 6336-6340. doi:10.1016/j. bmcl.2013.09.071

Lobo, V., Patil, A., Phatak, A., \& Chandra, N. (2010). Free radicals, antioxidants and functional foods: Impact on human health. Pharmacognosy reviews, 4(8), 118.

Luo, C., \& Wu, X.-G. (2011). Lycopene enhances antioxidant enzyme activities and immunity function in n-methyl-n-nitron-nitrosoguanidine-induced gastric cancer rats. International Journal of Molecular Sciences, 12(5), 3340-3351. doi:10.3390/ ijms12053340

Macheix, J. J., Fleuriet, A., \& Billot, J. (1990). Fruit phenolics. CRC Press: Boca Raton, FL, USA, 101-126.

Madhuri, B. A., Qairunnisa, S., Suresh, M., Kondam, K. A., \& Chandrasekhar, M. (2014). Antioxidant changes in wistar albino rats after acute heat stress. International Journal of Pharmaceutical Sciences and Research, 5(9), 3999.

Meda, A., Lamien, C. E., Romito, M., Millogo, J., \& Nacoulma, O. G. (2005). Determination of the total phenolic, flavonoid and proline contents in burkina fasan honey, as well as their radical scavenging activity. Food Chemistry, 91(3), 571-577. doi:10. 1016/j.foochem.2004.10.006

Mukherjee, P. K., Kumar, V., Mal, M. \& Houghton, P. J. (2007). Acetylcholinesterase inhibitors from plants. Phytomedicine, 14(4), 289-300.

Nimse, S. B., \& Pal, D. (2015). Free radicals, natural antioxidants, and their reaction 
mechanisms. RSC Advances, 5(35), 2798628006. doi:10.1039/c4ra13315c

Oboh, G., \& Ademosun, A. O. (2011). Shaddock peels (citrus maxima) phenolic extracts inhibit alpha-amylase, alpha-glucosidase and angiotensin i-converting enzyme activities: A nutraceutical approach to diabetes management. Diabetes 83 Metabolic Syndrome: Clinical Research \&3 Reviews, 5(3), 148152. doi:10.1016/j.dsx.2012.02.008

Ohkawa, H., Ohishi, N., \& Yagi, K. (1979). Assay for lipid peroxides in animal tissues by thiobarbituric acid reaction. Analytical Biochemistry, 95(2), 351-358. doi:10.1016/ 0003-2697(79)90738-3

Omoba, O. S., Dada, O. O., \& Salawu, S. O. (2015). Antioxidant properties and consumer acceptability of pearl millet - tiger nut biscuits. Nutrition 83 Food Science, 45(6), 818-828. doi:10.1108/NFS-06-20150074

Oyaizu, M. (1986). Studies on products of browning reaction. antioxidative activities of products of browning reaction prepared from glucosamine. Japanese Journal of Nutrition, 44, 307-314. doi:10.5264/ eiyogakuzashi.44.307

Pellegrino, D. (2016). Antioxidants and cardiovascular risk factors. Diseases, 4, 11. doi:10. 3390/diseases4010011

Ranilla, L., Genovese, M., \& Lajolo, F. (2007). Polyphenols and antioxidant capacity of seed coat and cotyledon from brazilian and peruvian bean cultivars ( phaseolus vulgaris 1.) Journal of Agricultural and Food Chemistry, 55, 90-8. doi:10.1021/jf062785j

Ross, D. A., Gutierrez-Botero, M., \& Van Amburgh, M. E. (2013). Development of an in vitro intestinal digestibility assay for ruminant feeds. 29, 29.

Saidu, A. N., \& Garba, R. (2011). Antioxidant activity and phytochemical screening of five species of capsicum fruits. International Research Journal of Biochemistry and Bioinformatics, 1(9), 237-241.

Salawu, S. O., Alao, O. F., Faloye, O. F., Akindahunsi, A. A., Boligon, A. A., \& Athayde, M. L. (2016). Antioxidant potential of phenolic-rich two varieties of nigerian local rice and their anti-cholinesterase activities after in vitro digestion. Nutrition $\&$ Food Science, 46(2), 171-189. doi:10.1108/NFS08-2015-0093

Salawu, S. O., Bester, M. J., \& Duodu, K. G. (2014). Phenolic composition and bioactive properties of cell wall preparations and whole grains of selected cereals and legumes. Journal of Food Biochemistry, 38(1), 62-72. doi:10.1111/jfbc.12026

Salawu, S. O., Ajiboye, P. B., Akindahunsi, A. A., \& Boligon, A. A. (2017). Antioxidant and anticholinesterase potential of two nigerian bitter yams using a simulated gastrointestinal digestion model and conventional extraction. Preventive nutrition and food science, 22(2), 107.

Sangameswaran, B., Balakrishnan, B. R., Deshraj, C., \& Jayakar, B. (2009). In vitro antioxidant activity of roots of thespesia lampas dalz and gibs. Pakistan Journal of Pharmaceutical Sciences, 22(4), 368-372.

Saura-Calixto, F., \& Goni, I. (2006). Antioxidant capacity of the spanish mediterranean diet. Food Chemistry, 94(3), 442-447. doi:10. 1016/j.foodchem.2004.11.033

Shahidi, F., \& Chandrasekara, A. (2013). Millet grain phenolics and their role in disease risk reduction and health promotion: A review. Journal of Functional Foods, 5(2), 570-581. doi:10.1016/j.jff.2013.02.004

Shi, J., Dai, Y., Kakuda, Y., Mittal, G., \& Xue, S. J. (2008). Effect of heating and exposure to light on the stability of lycopene in tomato puree. Food Control, 19(5), 514520. doi:10.1016/j.foodcont.2007.06.002

Skrovankova, S., Sumczynski, D., Mlcek, J., Jurikova, T., \& Sochor, J. (2015). Bioactive compounds and antioxidant activity in different types of berries. International Journal of Molecular Sciences, 16(10), 2467324706. doi:10.3390/ijms161024673

Szwajgier, D. (2014). Anticholinesterase activities of selected polyphenols - a short report. Polish Journal of Food and Nutrition Sciences, 64 (1), 59-64. doi:10.2478/v10222012-0089-x

Szydlowska-Czerniak, A., Trokowski, K., Karlovits, G., \& Szlyk, E. (2011). Effect of refining processes on antioxidant capacity, total contents of phenolics and carotenoids 
Nutraceutical potential of tomato products after in vitro digestion |SI51

in palm oils. Food Chemistry, $129(3), 1187-$ 1192. doi:10.1016/j.foodchem.2011.05.101

Tagliazucchi, D., Verzelloni, E., Bertolini, D., \& Conte, A. (2010). In vitro bio-accessibility and antioxidant activity of grape polyphenols. Food Chemistry, 120(2), 599-606. doi:10.1016/j.foodchem.2009.10.030

Toor, R. K., \& Savage, G. P. (2005). Antioxidant activity in different fractions of tomatoes. Food Research International, 38(5), 487494. doi:10.1016/j.foodres.2004.10.016

Uttara, B., Singh, A. V., Zamboni, P., \& Mahajan, R. T. (2009). Oxidative stress and neurodegenerative diseases: A review of upstream and downstream antioxidant therapeutic options. Current Neuropharmacology, 7(1), 65-74. doi:10 . 2174/ 157015909787602823

Vallverdu-Queralt, A., Medina-Remon, A., Martinez-Huelamo, M., Jauregui, O., Andres-Lacueva, C., \& Maria LamuelaRaventos, R. (2011). Phenolic profile and hydrophilic antioxidant capacity as chemotaxonomic markers of tomato varieties. Journal of Agricultural and Food Chemistry, 59(8), 3994-4001. doi:10.1021/jf104400g

Vinholes, J., Grosso, C., Andrade, P. B., GilIzquierdo, A., Valentao, P., de Pinho, P. G., \& Ferreres, F. (2011). In vitro studies to assess the antidiabetic, anti-cholinesterase and antioxidant potential of spergularia rubra. Food Chemistry, 129(2), 454-462. doi:10.1016/j.foodchem.2011.04.098

Violeta, N., Trandafir, I., \& Ionica, M. E. (2013). Antioxidant compounds, mineral content and antioxidant activity of several tomato cultivars grown in southwestern romania. Notulae Botanicae Horti Agrobotanici ClujNapoca, 41(1), 136-142.

Worthington Enzyme Manual. (2009). Worthington biochemical corporation. Retrieved from http: / / www. worthington-biochem. com/index/manual.html

Yafang, S., Gan, Z., \& Jinsong, B. (2011). Total phenolic content and antioxidant capacity of rice grains with extremely small size. African Journal of Agricultural Research, 6(10), 2289-2293.
Zhang, Y.-J., Gan, R.-Y., Li, S., Zhou, Y., Li, A.-N., Xu, D.-P., \& Li, H.-B. (2015). Antioxidant phytochemicals for the prevention and treatment of chronic diseases. Molecules, 20(12), 21138-21156. doi:10 . $3390 /$ molecules201219753 